\title{
A NEW THREE-DIMENSIONAL CHAOTIC SYSTEM WITHOUT EQUILIBRIUM POINTS, ITS DYNAMICAL ANALYSES AND ELECTRONIC CIRCUIT APPLICATION
}

\author{
Akif Akgul, Ihsan Pehlivan
}

Original scientific paper

In this paper, a new three-dimensional chaotic system without equilibrium points is introduced and analysed. Basic dynamical analysis of this new chaotic system without equilibrium points is carried out by means of system equilibria, phase portraits, sensitivity to initial conditions, fractal dimension and chaotic behaviours. In addition, in this paper Lyapunov exponents spectrum and bifurcation analysis of the proposed chaotic system have been executed by means of selected parameters. The chaotic system without equilibrium points has been executed by detailed theoretical analysis as well as simulations with designed electronical circuit. A chaotic system without equilibrium points is also known as chaotic system with hidden attractor and there are very few researches in the literature. Since they cannot have homoclinic and heteroclinic orbits, Shilnikov method cannot be applied to find whether the system is chaotic or not. Therefore, it can be useful in many engineering applications, especially in chaos based cryptology and coding information. Furthermore, introduced chaotic system without equilibrium points in this paper can have many unknown dynamical behaviours. These behaviours of the strange chaotic attractors deserve further investigation.

Keywords: bifurcation; chaotic circuit; chaotic systems; chaotic system without equilibrium points; dynamical analyses; equilibrium points; Lyapunov exponents

\section{Novi trodimenzijski kaotični sustav bez točaka ekvilibrija, njegove dinamičke analize i primjena elektroničkih krugova}

Izvorni znanstveni članak

U radu se predstavlja i analizira novi trodimenzionalni kaotični sustav bez točaka ekvilibrija. Osnovna dinamička analiza tog novog kaotičnog sustava bez točaka ekvilibrija izvodi se pomoću sustava ekvilibrija, faznih slika (portreta), osjetljivosti na početne uvjete, fraktalne dimenzije i kaotičnog ponašanja. Uz to je izvedena analiza spektra Lyapunovljevih eksponenata i bifurkacijska analiza predloženog kaotičnog sustava primjenom izabranih parametara. Kaotični sustav bez točaka ekvilibrija dobiven je detaljnom teorijskom analizom kao i simulacijama s dizajniranim elektroničkim krugom. Sustav kaosa bez točaka ekvilibrija također je poznat kao sustav kaosa sa skrivenim atraktorom i o tome postoji mali broj istraživanja. Budući da ne postoje homokliničke i heterokliničke orbite, Schilnikova metoda se ne može primijeniti kako bi se ustanovilo je li sustav kaotičan ili nije kaotičan. Stoga kaotični sustav bez točaka ekvilibrija može biti od koristi u mnogim tehničkim primjenama, naročito u kriptologiji i kodiranju zasnovanom na kaosu. Nadalje, ovaj predloženi kaotični sustav bez točaka ekvilibrija može se ponašati na mnogo dinamički nepoznatih načina. Takve vrste ponašanja nepoznatih kaotičnih atraktora zahtijevaju dodatna istraživanja.

Ključne riječi: bifurkacija; dinamička analiza; kaotični krug; kaotični sustavi; kaotični sustav bez ekvilibrijskih točaka; Lyapunovi eksponenti; točke ekvilibrija

\section{Introduction}

Chaotic dynamical equation research is an important problem in nonlinear science. Chaotic systems have been widely studied within scientific and engineering environments in the last years $[1 \div 23]$. It is possible to classify some existing 3D autonomous chaotic systems with standard parameter values. Case 1 covers chaotic attractors with 1 saddle and 2 unstable saddle-foci, like the Lu system [6], and Chen system [7], and Case 2 covers attractors having 2 unstable saddle-foci, like DLS [8], the Rössler system [9], and the Burke-Shaw system $[10,19]$. Case 3 covers chaotic attractors with 1 saddle and 2 stable node-foci. For instance, another such 3D chaotic system was introduced by Yang and Chen [11] Pehlivan and Uyaroglu [12] and Yang et al. [13] recently designed novel chaotic systems with 2 stable node-foci.

Chaotic systems with no equilibria have been

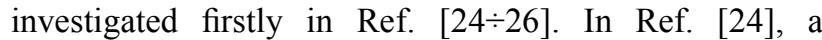
systematic search to find 3D chaotic systems with quadratic nonlinearities and no equilibria was performed. Since they cannot have homoclinic and heteroclinic orbits, the Shilnikov method [27] cannot be applied to no equilibria systems. Chaotic system without equilibrium points is named as chaotic system with hidden attractor $[28,29]$.

In this study, a new three-dimensional chaotic system without equilibrium points is discussed. For the new system, dynamical analyses such as equilibria, phase portraits, Lyapunov exponent spectrum, fractal dimension and bifurcation analysis were performed with Matlab programme in the first part. In the second part, electronic circuit of the new chaotic system was designed in OrCAD-PSpice programme and phase portraits were observed. The last part includes the results and evaluations.

\section{The new chaotic system and its properties}

The new chaotic system without equilibrium points is described by the following differential equation 1 :

$$
\begin{aligned}
& \dot{x}=a y-x+z y \\
& \dot{y}=-b x z-c x+y z+d \\
& \dot{z}=e-f x y-x^{2}
\end{aligned}
$$

Initial values of the new chaotic system are $x(0)=0, y(0)$ $=0, z(0)=0$ and ten terms and six parameters $(a, b, c, d, e$ and $f$ ). Typical parameters are $a=2,8, b=0,2, c=1,4, d$ $=1, e=10$ and $f=2$. The new system can be described using typical parameters by the following Eq. (2):

$$
\begin{aligned}
& \dot{x}=2,8 y-x+z y \\
& \dot{y}=-0,2 x z-1,4 x+y z+1 \\
& \dot{z}=10-2 x y-x^{2}
\end{aligned}
$$




\subsection{System equilibria}

The equilibria of the system are found by settings $\dot{x}=\dot{y}=\dot{z}=0$. The system has four complex number equilibrium points:

$\mathrm{E}_{1}(2,707+0,573 \cdot i ; 0,413-0,661 \cdot i ;-1,584+3,332 \cdot i)$

$\mathrm{E}_{2}(2,707-0,573 \cdot i ; 0,413+0,661 \cdot i ;-1,584-3,332 \cdot i)$

$\mathrm{E}_{3}(-2,962-0,739 \cdot i ;-0,107+0,766 \cdot i ;-3,215+3,924 \cdot i)$

$\mathrm{E}_{4}(-2,962+0,739 \cdot i ;-0,107-0,766 \cdot i ;-3,215-3,924 \cdot i)$

Since there are not real equilibrium points, the four equilibrium points $E_{1}, E_{2}, E_{3}$ and $E_{4}$ are complex. Because the new chaotic system does not have equilibrium points, the new system is without equilibrium points. The local behaviour of the system around these complex number equilibrium points can be investigated by using the following Jacobian matrix:

$$
J(x, y, z)=\left[\begin{array}{ccc}
-1 & a+z & y \\
-b z-c & z & -b x+y \\
-f y-2 x & -f x & 0
\end{array}\right]
$$

For the complex number equilibrium point $\mathrm{E}_{1}$, the Jacobian matrix becomes the following Eq. (5):

$J\left(\mathrm{E}_{1}\right)\left[\begin{array}{ccc}-1 & 1,215+3,332 \cdot i & 0,413-0,661 \cdot i \\ -1,083-0,666 \cdot i & -1,584+3,332 \cdot i & -0,128-0,776 \cdot i \\ -6,242+0,175 \cdot i & -5,4151-1,147 \cdot i & 0\end{array}\right]$

To obtain its eigenvalues, let $\operatorname{det}\left(\lambda \cdot I-J\left(\mathrm{E}_{1}\right)\right)=0$. Then, the characteristic equation has the following form:

$\lambda^{3}+(2,584-3,332 \cdot i) \cdot \lambda^{2}+(3,341-7,466 \cdot i) \cdot \lambda-$ $-(0,280-26,838 \cdot i)=0$.

Solving the above characteristic equation, the eigenvalues are found as

$\lambda_{1}=1,020+2,941 \cdot i$

$\lambda_{2}=-1,068-2,149 \cdot i$

$\lambda_{3}=-2,537+2,540 \cdot i$

Similarly, for the equilibrium points $E_{2}, E_{3}$ and $E_{4}$, we have the corresponding eigenvalues, respectively;

for $\mathrm{E}_{2}$ :

$\lambda_{1}=1,020-2,941 \cdot i$

$\lambda_{2}=-1,068+2,149 \cdot i$

$\lambda_{3}=-2,537-2,540 \cdot i$

for $\mathrm{E}_{3}$ :

$$
\begin{aligned}
& \lambda_{1}=1,289+3,078 \cdot i \\
& \lambda_{2}=-1,177-1,500 \cdot i \\
& \lambda_{3}=-4,327+2,346 \cdot i
\end{aligned}
$$

and for $\mathrm{E}_{4}$,

$$
\begin{aligned}
& \lambda_{1}=1,289-3,078 \cdot i \\
& \lambda_{2}=-1,177+1,500 \cdot i \\
& \lambda_{3}=-4,327-2,346 \cdot i
\end{aligned}
$$

\subsection{Sensitivity to initial conditions}

Sensitivity to initial conditions means that any arbitrarily small perturbations in the initial state of the system can lead to the significantly distant behaviour of the future state of the chaotic system. This dependence of initial conditions in the system makes the long term prediction impossible. Obtained time series using ode 45 function for $x 1(0)=0$ and $x 2(0)=0,001$ are given in Fig. 1. It shows that the evolution of the chaos trajectories is very sensitive to initial conditions.

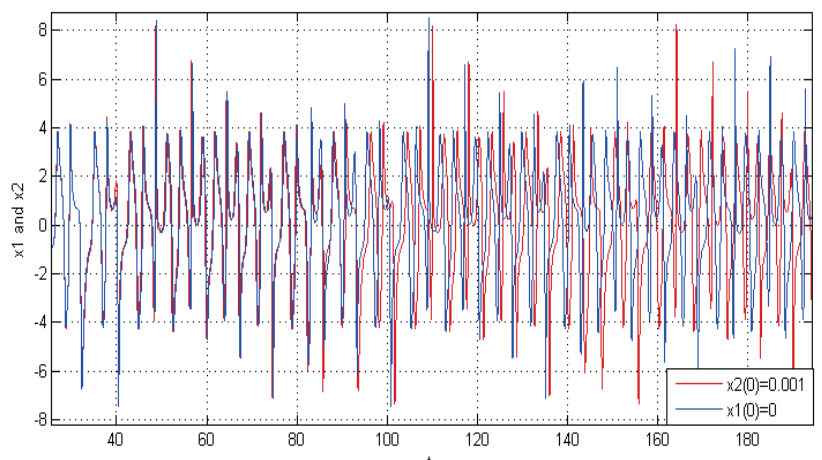

Figure 1 Time series for $x 1(0)=0$ and $x 2(0)=0,001$

\subsection{Phase portraits}

The initial values of the new chaotic system without equilibrium points are given as $(0,0,0)$ and its simulations have been realized for the phase portraits. This new chaotic system exhibits rich dynamic behaviors. We show the $y-z, x-y, x-z$ and $x-y-z$ phase portraits of the new chaotic system using Matlab ode45 function in Fig. 2.

\subsection{Lyapunov exponents spectrum and fractional dimension}

Fig. 3 shows the Lyapunov exponents spectrum of the new system without equilibrium points for a varying parameter $b$. As can be seen from the Lyapunov exponents spectrum, $b$ is changed in the range of $0 \div 1$. The system is chaotic when the first Lyapunov exponent (blue line) is positive, the second Lyapunov exponent (green line) is zero and the third Lyapunov exponent (red line) is negative.

Fig. 4 shows detailed Lyapunov exponents spectrum when $b$ is changed in the range $0,05 \div 0,47$.

The Lyapunov exponent is a way for analyzing the nonlinear behaviour of the dynamical system. If there is at least one positive Lyapunov exponent, the system is chaotic. The Lyapunov exponents of the system are computed numerically with the parameter values $a=2,8$, $b=0,1, c=1,4, d=1, e=10$ and $f=2$ and the initial conditions chosen as $x(0)=(0,0,0)$. The corresponding values for the Lyapunov exponents are $L_{1}=0,1403$, $L_{2}=0, L_{3}=-2,1515$. 

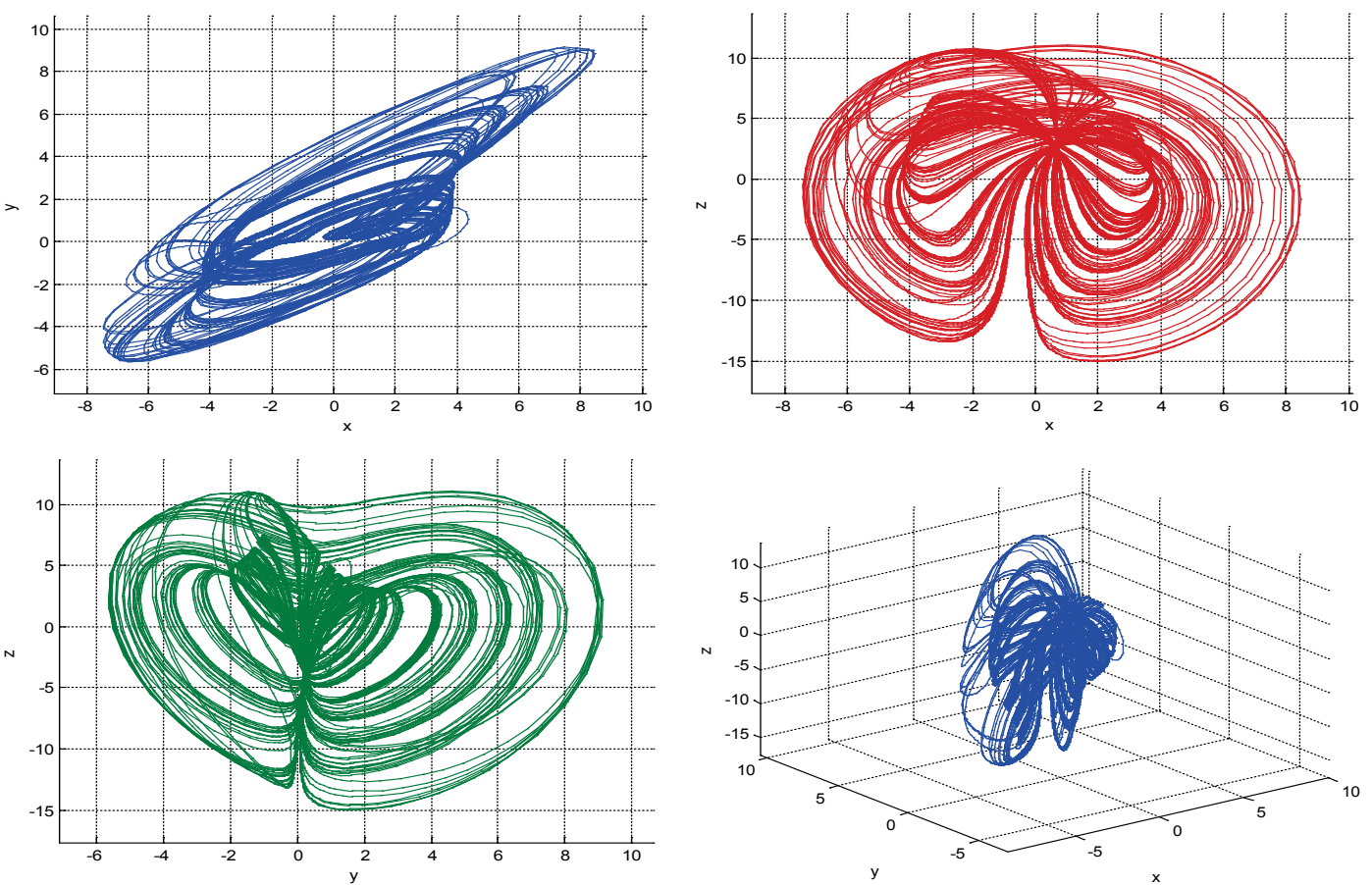

Figure 2 Phase portraits using Matlab ode45 function (the $x-y, x-z, y-z$ and $x-y-z$ )

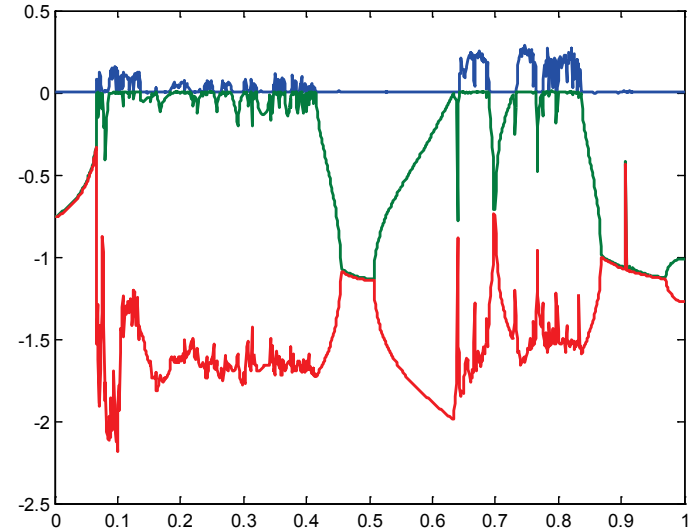

Figure 3 The Lyapunov exponents spectrum of the new system when $b$ is changed $0 \div 1$

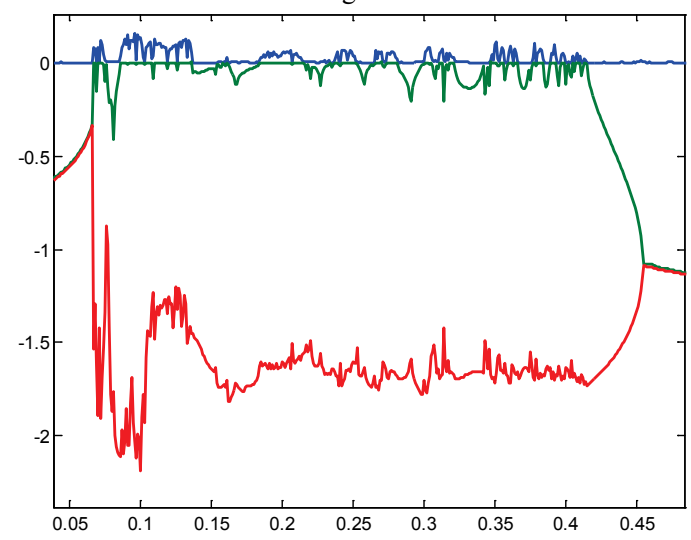

Figure 4 The Lyapunov exponents spectrum of the new system when $b$ is changed $0,05 \div 0,47$

The Lyapunov dimension of the new chaotic system without equilibrium points is given by

$D_{L}=j+\frac{1}{\left|L_{j}+1\right|} \sum_{i=1}^{j} L_{i}=2+\frac{L_{1}+L_{2}}{\left|L_{3}\right|}=2,0652103183 .(10)$
Eq. (10) means the system is really a threedimensional chaotic system and the Lyapunov dimensions of the system are fractional. Having a strange attractor and positive Lyapunov exponent, it is obvious that the system is chaotic.

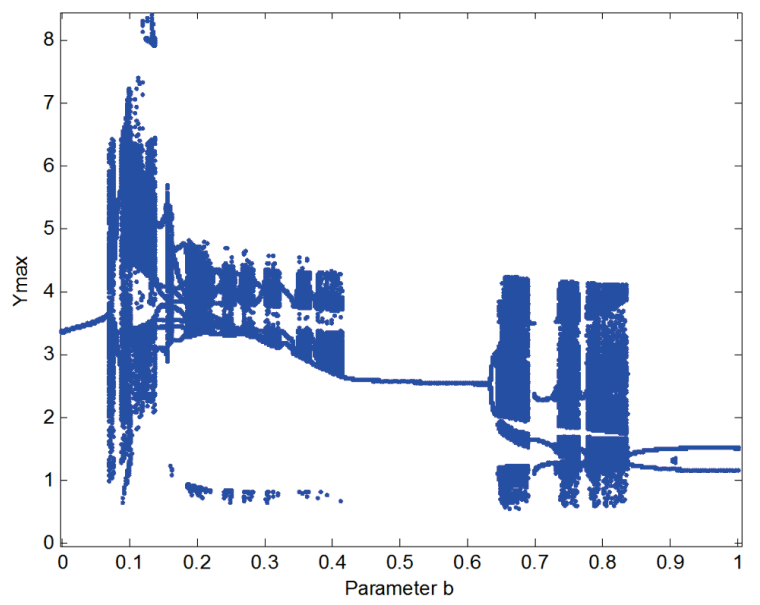

Figure 5 Bifurcation diagram (between 0-1)

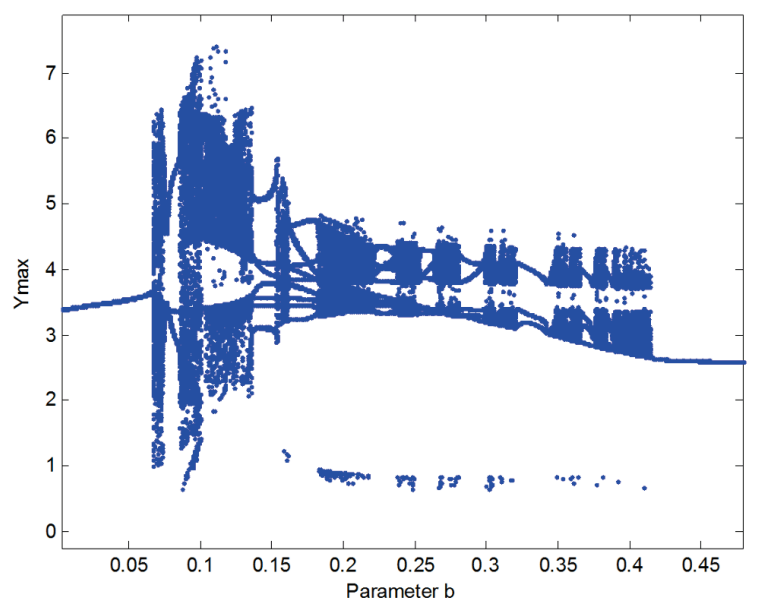

Figure 6 Bifurcation diagram (between $0,05 \div 0,47$ ) 


\subsection{Bifurcation analysis}

Figs. 5 and 6 show the bifurcation diagrams which correspond directly to the maximum Lyapunov exponent spectrum, shown in Figs. 3 and 4. As can be seen in Fig. 5 the new system has chaotic behaviour between $0,07 \div$ 0,41 and $0,66 \div 0,85$ for $a=2,8, c=1,4, d=1, e=10$ and $f=2$. In some intervals, system is not chaotic like between $0,41 \div 0,66$.

In Fig. 6, detailed chaotic status in bifurcation diagram when ' $b$ ' is changed in the range $0,05 \div 0,47$ is given.

\section{Circuit implementation}

The electronic circuit of the new chaotic system was designed in OrCAD-PSpice programme. The electronic circuit schematic of the new system is seen in Fig. 7. The circuit includes simple electronic elements such as resistors, operational amplifiers, and is easy to construct.

Experimental electronic circuit of the new chaotic system was designed for parameter $a=2,8, b=0,2, \mathrm{c}=$ $1,4, d=1, e=10, f=2$, and initial conditions $x(0)=0$, $y(0)=0, z(0)=0$. Since it does not require the initial condition voltages for executing the circuit, realization of the new circuit in real time is easy.

The OrCAD-PSpice simulation oscilloscope outputs (phase portraits) of circuitry of the new system without equilibrium points, for parameters $a=2,8, b=0,2, c=$ $1,4, d=1, e=10$ and $f=2$, are seen in Fig. $8 \div 10$. As they can be seen from the Matlab ode45 function simulation outputs in Fig. 2 and the OrCAD-PSpice simulation outputs in Fig. 8, the results are the same.
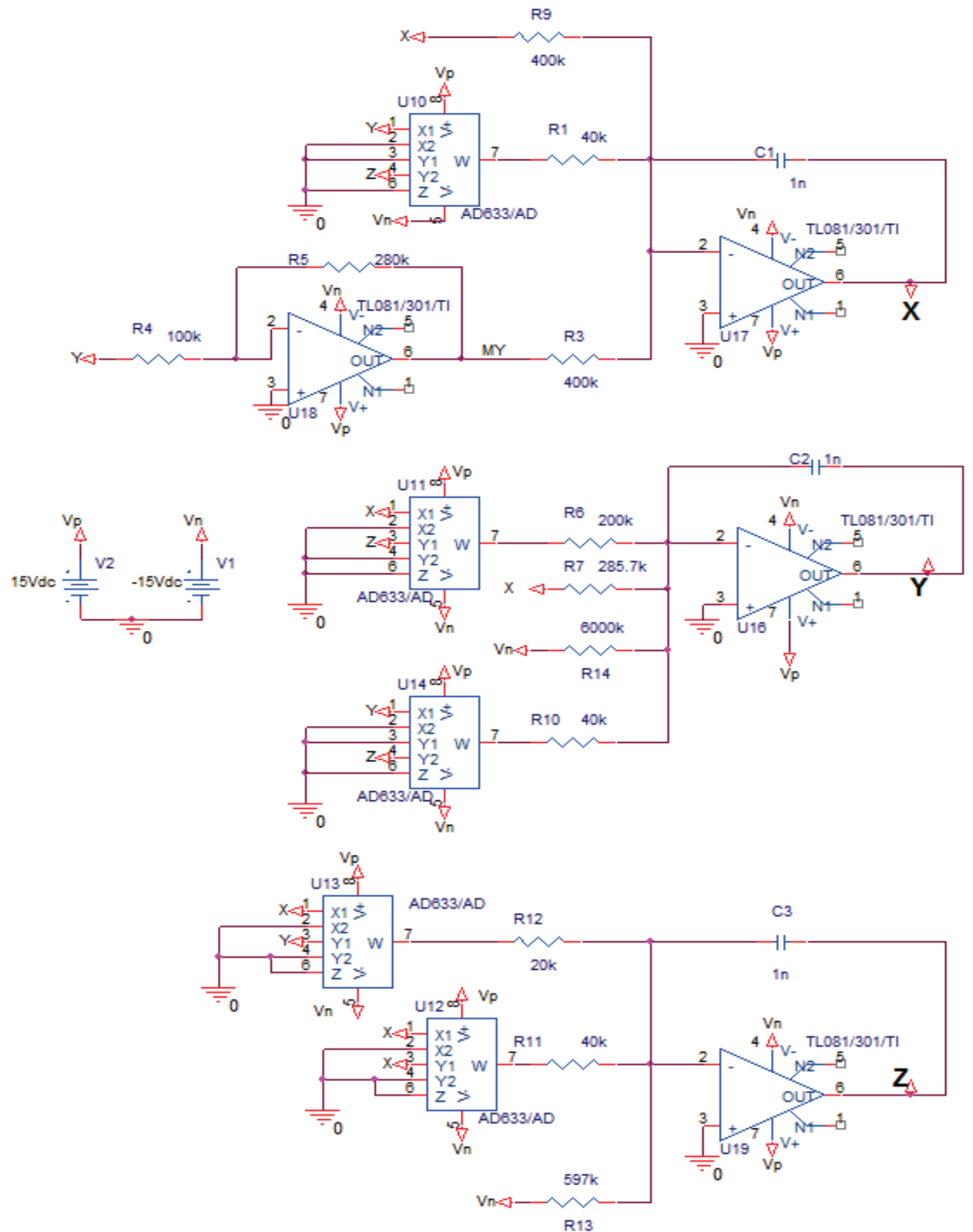

Figure 7 The electronic circuit schematic of the new chaotic system without equilibrium points 


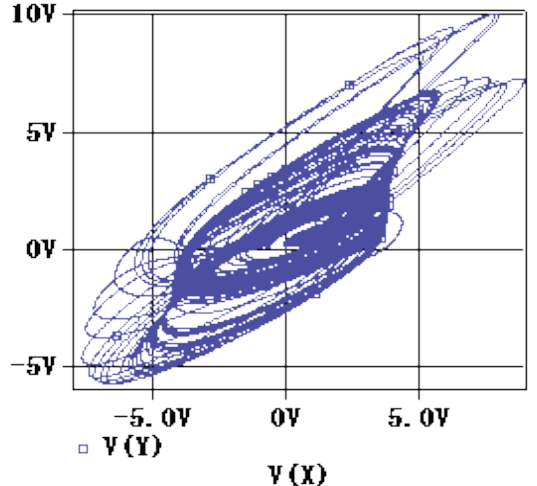

Figure 8 Phase portraits obtained from OrCAD-PSpice Simulation $(x-y)$

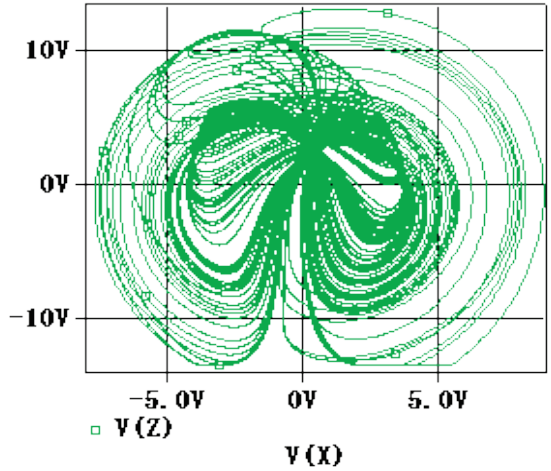

Figure 9 Phase portraits obtained from OrCAD-PSpice Simulation $(x-z)$

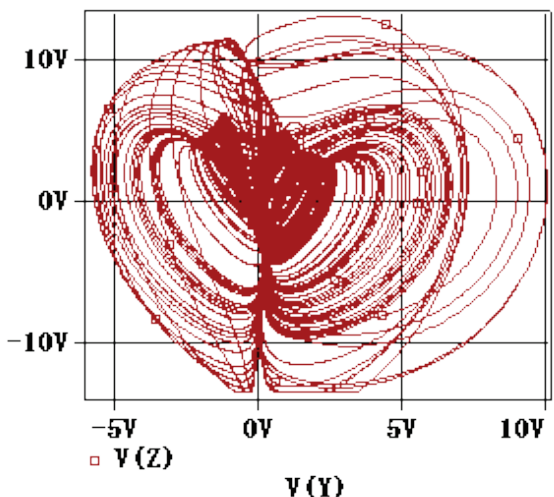

Figure 10 Phase portraits obtained from OrCAD-PSpice Simulation $(y-z)$

\section{Results and evaluation}

The studies about chaotic systems without equilibrium points are very few in the literature. In this paper, a new three-dimensional chaotic system without equilibrium points is discussed. Dynamical properties of the new system were analysed by means of equilibrium points, phase portraits, sensitivity to initial conditions, fractal dimension and chaotic behaviours. Moreover, Lyapunov spectrum and bifurcation analysis have been executed by means of selected parameters. In all analysis, MATLAB programme was used. The results of analysis show that the new chaotic system has no equilibria. So, the new system is a chaotic system without equilibrium points.

Also, it is a new hidden chaotic attractor, too. Since they cannot have homoclinic and heteroclinic orbits, Shilnikov method cannot be applied to find whether the system is chaotic or not. Because of the hidden attractors in the proposed new chaotic system, they can be useful in many engineering applications such as chaos based cryptology, coding information, information compression, random number generator, chaos based music and image generator, etc. in the near future.

In this paper, in addition to basic dynamical analysis, the new chaotic system without equilibrium points has been executed for its simulations using the designed electronical circuit in OrCADPSpice programme. The new chaotic system without equilibrium points is confirmed through electronic circuit design. The simulation results of the Matlab and the OrCAD-PSpice programs were obtained for the same shaped phase portraits.

\section{References}

[1] Sprott, J. C. A new class of chaotic circuit. // Physics Letters A. 266, (2000), pp. 19-23. DOI: 10.1016/S03759601(00)00026-8

[2] Li, C.; Pehlivan, I.; Sprott, J. C. Amplitude-phase control of a novel chaotic attractor. //Turkish Journal of Electrical Engineering and Computer Sciences. 24, (2016), pp. 1-11. DOI: 10.3906/elk-1301-55

[3] Sprott, J. C. Simple chaotic systems and circuits. // American Journal of Physics. 68, (2000), pp. 758-763. DOl: 10.1119/1.19538

[4] Ahmad, W. M.; Sprott, J. C. Chaos in fractional-order autonomous nonlinear systems. // Chaos, Solitons and Fractals 16, (2003), pp. 339-351. DOI: 10.1016/S09600779(02)00438-1

[5] Piper, J. R.; Sprott, J. C. Simple autonomous chaotic circuits. // Circuits and Systems II: Express Briefs, IEEE Transactions on. 57, (2010), pp. 730-734. DOI: 10.1109/TCSII.2010.2058493

[6] Lu, C.; Chen, A. A new chaotic attractor coined. // International Journal of Bifurcation and Chaos. 12, (2002), pp. 659-661. DOI: 10.1142/S0218127402004620

[7] Chen, G.; Ueta, T. Yet another chaotic attractor. // International Journal of Bifurcation and Chaos. 9, (1999), pp. 1465-1466. DOI: 10.1142/S0218127499001024

[8] Van der Schrier, G.; Maas, L. R. M. The diffusionless Lorenz equations; Shil'nikov bifurcations and reduction to an explicit map. // Physica D. 141, (2000), pp. 19-36. DOI: 10.1016/S0167-2789(00)00033-6

[9] Rossler, O. E. An equation for continuous chaos. // Physics Letters A. 57, (1976), pp. 397-398. DOI: 10.1016/03759601(76)90101-8

[10] Shaw, R. Strange attractor, chaotic behavior and information flow. // Zeitschrift fur Naturforschung A. 36, (1981), pp. 80-112. DOI: 10.1515/zna-1981-0115

[11] Yang, Q. G.; Chen, G. R. A chaotic system with one saddle and two stable node-foci. // International Journal of Bifurcation and Chaos. 18, (2008), pp. 1393-1414. DOI: 10.1142/S0218127408021063

[12] Pehlivan, I.; Uyaroglu, Y. A new chaotic attractor from general Lorenz system family and its electronic experimental implementation. // Turkish Journal of Electrical Engineering and Computer Sciences. 18, (2010), pp. 171-184.

[13] Yang, Q. G.; Wei, Z. C.; Chen, G. R. An unusual 3D autonomous quadratic chaotic system with two stable nodefoci. // International Journal of Bifurcation and Chaos. 20, (2010), pp. 1061-1083. DOI: 10.1142/S0218127410026320

[14] Pehlivan, I. Four-scroll stellate new chaotic system. // Optoelectronics and Advanced Materials Rapid Communications. 5, 9(2011), pp. 1003-1006. 
[15] Pehlivan, I.; Uyaroglu, Y. A new 3D chaotic system with golden proportion equilibria: Analysis and electronic circuit realization. // Computers and Electrical Engineering. 38, 6(2012), pp. 1777-1784. DOI: 10.1016/j.compeleceng.2012.08.007

[16] Pehlivan, I.; Wei, Z. Analysis, nonlinear control and circuit design of an another strange chaotic system. // Turkish Journal of Electrical Engineering and Computer Sciences. 20, 2(2012), pp. 1229-1239.

[17] Pehlivan, I.; Moroz, I. M.; Vaidyanathan, S. Analysis, synchronization and circuit design of a novel butterfly attractor. // Journal of Sound and Vibration. 333, (2014), pp. 5077-5096. DOI: 10.1016/j.jsv.2014.05.025

[18] Koyuncu, I.; Ozcerit, A. T.; Pehlivan, I. Implementation of FPGA-based real time novel chaotic oscillator. // Nonlinear Dynamics. 77, 1-2(2014), pp. 49-59. DOI: 10.1007/s11071014-1272-x

[19] Koyuncu, I.; Ozcerit, A. T.; Pehlivan, I. An analog circuit design and FPGA-based implementation of the Burke-Shaw chaotic system. // Optoelectronics and Advanced MaterialsRapid Communications. 7, 9-10(2013), pp. 635-638.

[20] Li, C.; Pehlivan, I.; Sprott, J. C.; Akgul, A. A novel fourwing strange attractor born in bistablity. // IEICE Electronics Express. 12, 14(2015), pp. 1-12.

[21] Li, C.; Sprott, J. C. Coexisting Hidden Attractors in a 4-D Simplified Lorenz System. // International Journal Bifurcation Chaos. 24, 3(2014), pp. 1450034-1 $\div 1450034$ 12.

[22] Li, X. F.; Chlouverakis, K. E.; Xu, D. L. Nonlinear dynamics and circuit realization of a new chaotic flow: A variant of Lorenz, Chen and Lu. // Nonlinear Analysis: Real World Applications. 10, 4(2009), pp. 2357-2368. DOI: 10.1016/j.nonrwa.2008.04.024

[23] Zhou, W.; Xu, Y.; Lu, H.; Pan, L. On dynamics analysis of a new chaotic attractor. // Physics Letters A. 372, 36(2008), pp. 5773-5777. DOI: 10.1016/j.physleta.2008.07.032

[24] Jafari, S.; Sprott, J. C.; Hashemi Golpayegani, S. M. R. Elementary quadratic chaotic flows with no equilibria. Physics Letters A. 377, 9(2013), pp. 699-702. DOI: 10.1016/j.physleta.2013.01.009

[25] Wie, Z. Dynamical behaviors of a chaotic system with no equilibria. // Phys Lett A. 376, (2011), pp. 102-108. DOI: 10.1016/j.physleta.2011.10.040

[26] Wang, Z.; Cang, S.; Ochola, E. O.; Sun, Y. A hyperchaotic system without equilibrium. // Nonlinear Dynamics. 69, (2012), pp. 531-537. DOI: 10.1007/s11071-011-0284-z

[27] Shilnikov, L.; Shilnikov, A.; Turaev, D.; Chua, L. Methods of Qualitative Theory in Nonlinear Dynamics - Part I. // World Scientific. 4, (1998).

[28] Leonov, G. A.; Kuznetsov, N. V; Vagaitsev, V. I. Localization of hidden Chua's attractors. // Phys. Lett. A. $375, \quad 23(2011), \quad$ pp. 2230-2233. DOI: 10.1016/j.physleta.2011.04.037

[29] Leonov, G. A.; Kuznetsov, N. V; Vagaitsev, V. I. Hidden attractor in smooth Chua systems. // Physica D 241, 18(2012), pp. 1482-1486. DOI: 10.1016/j.physd.2012.05.016

\section{Authors' addresses}

Akif Akgul, Arş. Gör. Dr.

Sakarya University, Faculty of Technology, Esentepe Campus,

54187 Serdivan/Sakarya, Turkey

E-mail: aakgul@sakarya.edu.tr

Ihsan Pehlivan, Doç. Dr.

Sakarya University, Faculty of Technology,

Esentepe Campus,

54187 Serdivan/Sakarya, Turkey

E-mail: ipehlivan@sakarya.edu.tr 